\title{
$\mathrm{Cu}-\mathrm{Fe}-\mathrm{P}$ 계 합금의 강도 및 전기전도도에 미치는 첨가 원소의 영향
}

\author{
김대현 ${ }^{\dagger}$ 이광학 \\ 울산대학교 첨단소재공학부
}

\section{Effects of Alloying Elements on the Tensile Strength and Electrical Conductivity of $\mathrm{Cu}-\mathrm{Fe}-\mathrm{P}$ Based Alloys}

\author{
Dae-Hyun $\mathrm{Kim}^{\dagger}$ and Kwang-Hak Lee \\ School of Material Science \& Engineering, Ulsan University, Daehak-ro 102, Nam-gu, Ulsan, 680-749, Korea \\ (2010년 1월 20일 접수 : 2010년 1월 25일 최종수정 : 2010년 1월 28일 채택)
}

\begin{abstract}
In this study, the effect of $\mathrm{Sn}$ and $\mathrm{Mg}$ on microstructure and mechanical properties of $\mathrm{Cu}-\mathrm{Fe}-\mathrm{P}$ alloy were investigated by using scanning electron microscope, transmission electron microscope, tensile strength, electrical conductivity, thermal softening, size and distribution of the precipitation phases in order to satisfy characteristic for lead frame material. It was observed that Cu-0.14wt\%Fe-0.03wt\%P-0.05wt\%Si-0.1wt\%Zn with $\mathrm{Sn}$ and Mg indicates increasing tensile strength compare with PMC90 since Sn restrained the growth of the Fe-P precipitation phase on the matrix. However, the electrical conductivity was decreased by adding addition of $\mathrm{Sn}$ and $\mathrm{Mg}$ because $\mathrm{Sn}$ was dispersed on the matrix and restrained the growth of the Fe-P precipitation.

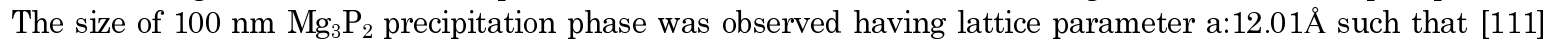
zone axis. According to the results of the study, the tensile strength and the electrical conductivity satisfied the requirements of lead frame; so, there is the possibility of application as a substitution material for lead frame of $\mathrm{Cu}$ alloy.
\end{abstract}

Key words $\mathrm{Fe}-\mathrm{P}$, precipitation, Mg-P, leadframe.

\section{1. 서 론}

석출경화형 합금으로 알려진 $\mathrm{Cu}-\mathrm{Fe}-\mathrm{P}$ 계 합금은 인장강 도 확보를 위하여 $\mathrm{Cu}-\mathrm{Cr}$ 계 및 $\mathrm{Cu}-\mathrm{Ni}-\mathrm{P}$ 계와 더불어 $\mathrm{Cu}$ 기지내에 $\mathrm{Fe}_{2} \mathrm{P}$ 등 제2상을 석출 시키고자 합금의 설계가 이루어진 대표적인 합금이다. 이에 따라 높은 인장강도, 우수한 전기전도도 및 뛰어난 내열성을 요구하는 반도체 용 $\mathrm{L} / \mathrm{F}$ 소재로써 상업용으로 널리 사용되고 있으나, 부품 의 소형화, 박판화 및 미세 pitch화에 따른 고인장강도 및 고내열특성이 필요로 되어지고 있다.

일반적인 재료 특성상 강도를 증가시키면 전기전도도 및 연성이 감소하는 경향을 나타내지만, 석출경화는 예 외적으로 강도와 전기전도도를 동시에 향상 시킬 수 있 다. 석출경화와 냉간가공을 적절히 병행하면 석출속도를 빠르게 하고 균일한 핵생성을 통하여 결정립 미세화를 유 도하며, 그에 따라서 강도와 연성을 증가 시킬 수 있기 때문에 동합금의 제조에 많이 이용되고 있다. 재료의 항 복강도는 고용강화, 가공경화, 석출경화 그리고 결정립 미

Corresponding author

E-Mail : daebalz@paran.com (D. -H. Kim)
세화 등에 의해 증가되지만, 고용강화는 전기전도도를 크 게 감소시키고, 순수한 가공경화는 온도상승과 더불어 쉽 게 그 효과가 없어진다. 반면, 석출경화는 강도와 전기전 도도를 동시에 증가시킬 수 있고, 또한 미세 석출물에 의 한 분산 강화 효과에 의해서 내연화성이 우수해지기 때 문에 고강도 및 고전도성 동합금개발에 가장 중요한 강 화 기구로 이용될 수 있다. ${ }^{1-12)}$

본 연구에서는 $\mathrm{Cu}-\mathrm{Fe}-\mathrm{P}$ 계 합금의 강도 및 전기전도도 를 향상시키기 위한 동합금 개발 기초연구를 진행하고자 하였으며, 일부 범용으로 사용되는, 전기전도도는 우수하 나 강도 저하로 부품 적용에 어려움이 있는 PMC90 소 재를 비교재로 하여, $\mathrm{Cu}-\mathrm{Fe}-\mathrm{P}$ 계 합금에서 미량의 $\mathrm{Sn}$ 및 $\mathrm{Mg}$ 성분 첨가가 미세조직과 물리적 특성에 미치는 영 향을 실험적으로 측정 및 비교 분석하였다.

\section{2. 실험 방법}

\section{1 용해 및 주조}

고주파 유도로에서 전해 $\mathrm{Cu}$ 에 $\mathrm{Fe}, \mathrm{P}, \mathrm{Zn}$ 을 첨가하고 여 기에 각각 $\mathrm{Sn}$ 및 $\mathrm{Mg}$ 을 첨가하여 합금을 제조하였고, 합 금 제조 시 산화되기 쉬운 $\mathrm{P}$ 은 $\mathrm{Cu}-15 \mathrm{wt} \% \mathrm{P}$ 모합금을 사 
Table 1. Chemical compositions of cast slabs (wt\%).

\begin{tabular}{ccccccc}
\hline Alloy & $\mathrm{Cu}$ & $\mathrm{Fe}$ & $\mathrm{P}$ & $\mathrm{Zn}$ & $\mathrm{Sn}$ & $\mathrm{Mg}$ \\
\hline 1 & Bal. & 0.146 & 0.038 & 0.107 & 0.053 & - \\
2 & Bal. & 0.144 & 0.036 & 0.106 & 0.102 & - \\
3 & Bal. & 0.143 & 0.036 & 0.107 & 0.156 & - \\
4 & Bal. & 0.147 & 0.037 & 0.105 & - & 0.047 \\
5 & Bal. & 0.146 & 0.039 & 0.104 & - & 0.089 \\
6 & Bal. & 0.145 & 0.039 & 0.103 & - & 0.211 \\
$7^{*}$ & Bal. & 0.143 & 0.035 & - & - & - \\
\hline
\end{tabular}

*Alloy 7 = PMC90

용하였으며, 용탕을 교반 시켜가면서 첨가 원소를 균질 하게 용해시켰다. 용해된 용탕을 진정시킨 후에 흑연몰드 $(20 \mathrm{~mm} \times 40 \mathrm{~mm} \times 180 \mathrm{~mm})$ 에 주입시켜 주괴를 제조하였 으며, 흑연몰드는 주조전 충분하게 예열시켰다. 주괴로부 터 시료를 채취하여 스팩트럼분석기(optical emission spectrometer)을 이용하여 주조 후 성분을 분석하였으며 비교 시편인PMC90 (Alloy 7)과 성분분석 결과를 Table 1에 나타내었다.

\section{2 시편제조 및 가공열처리}

주괴는 Fig. 1에 나타낸 공정순으로 가공하였으며, 1.5 $\mathrm{mm}$ 두께로 냉간 압연된 재료를 시험용 압연기에서 다시 $0.4 \mathrm{~mm}$ 두께로 냉간 압연하였다. 이 냉간 압연된 시료는 $650^{\circ} \mathrm{C}$ 에서 1 분간 열처리를 실시하여 시편에 내재된 잔류

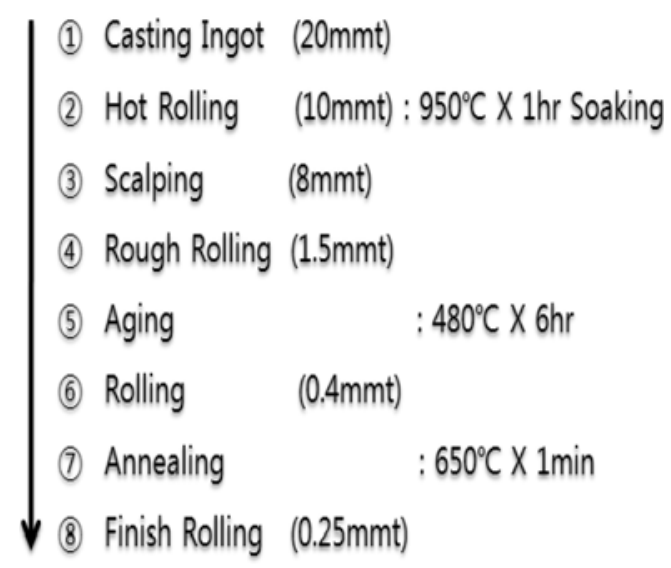

Fig. 1. Processing of specimens.

응력을 제거하였으며, 열처리 후의 소재는 $0.25 \mathrm{~mm}$ 두 께로 냉간 압연한 후 최종 특성평가를 하였다.

\section{3 내열특성 평가}

두께 $1.5 \mathrm{~mm}$ 까지 냉간압연한 재료를 시험로에서 $480^{\circ} \mathrm{C}$ 에서 2 6시간 시효처리를 행한 후 경도 및 전기전도도 를 측정하여 시효처리 조건에 따른 물성의 변화를 조사 하였다. 시험로에서 $200^{\circ} \mathrm{C}-800^{\circ} \mathrm{C}$ 로 30 분간 가열한 후 $1 \mathrm{kgf}$ 하중으로 Vickers 경도를 측정해 최초경도의 $80 \%$ 가 유지되는 온도를 산출하였고, 이를 내연화 온도로 정 의하였다.
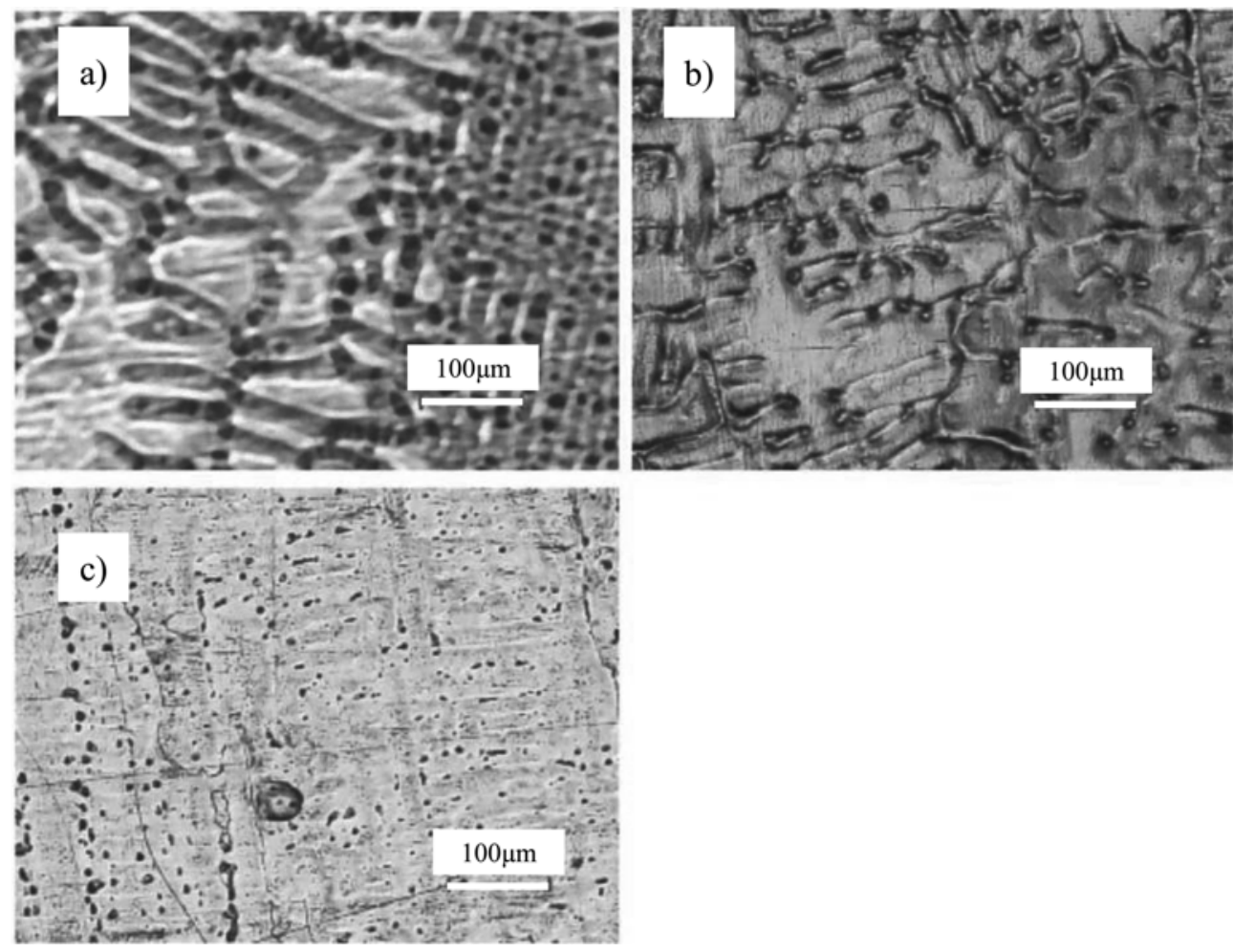

Fig. 2. Macrostructure of ingots for various kinds of additional elements. a) PMC 90, b) Sn:0.102\% and c) Mg:0.089\%. 


\section{4 시편 조직 관찰}

마이크로조직을 관찰하기 위하여 시편의 절단면을 $\mathrm{SiC}$ paper \#1,500까지 연마 후 미세조직 관찰을 위해 $4 \mathrm{ml}$ 의 질산, $3 \mathrm{ml}$ 의 황산, $1 \mathrm{~g}$ 의 염화암모늄, $3.5 \mathrm{~g}$ 의 중크롬산 칼륨과 물 $100 \mathrm{ml}$ 비율로 섞은 용액에 15 초동안 부식 시 킨 후, $\mathrm{OM}, \mathrm{SEM}$ 및 $\mathrm{TEM}$ 을 통하여 미세조직 및 석출 상을 비교 평가를 실시 하였다.

\section{5 전기전도도 특성}

샘플소재로 전기전도도 측정은 Kelvin type double bridge (Yokogawa)을 사용하여 전기저항을 측정하였으며, 중량법 으로 산출하였다. 시편길이는 $650 \mathrm{~mm}$ 로 하여 시편 양 끝 에 $3 \mathrm{~A}$ 의 일정전류를 흘려 전기 저항 $(\mathrm{R})$ 을 측정하여 최 종 전기전도도로 환산하였다.

\section{6 기계적 성질 평가}

\subsection{1 인장시험}

최종 $0.25 \mathrm{~mm}$ 로 냉간압연된 소재로 압연방향에 평행 하게 가공한 JIS 시편을 제작하였으며, 만능재료시험기 (Universal testing machine, Instron, model 1137)에서 최 대하중 2.5 ton, Cross head speed $30 \mathrm{~mm} / \mathrm{min}$ 의 조건으 로 시험하였다.
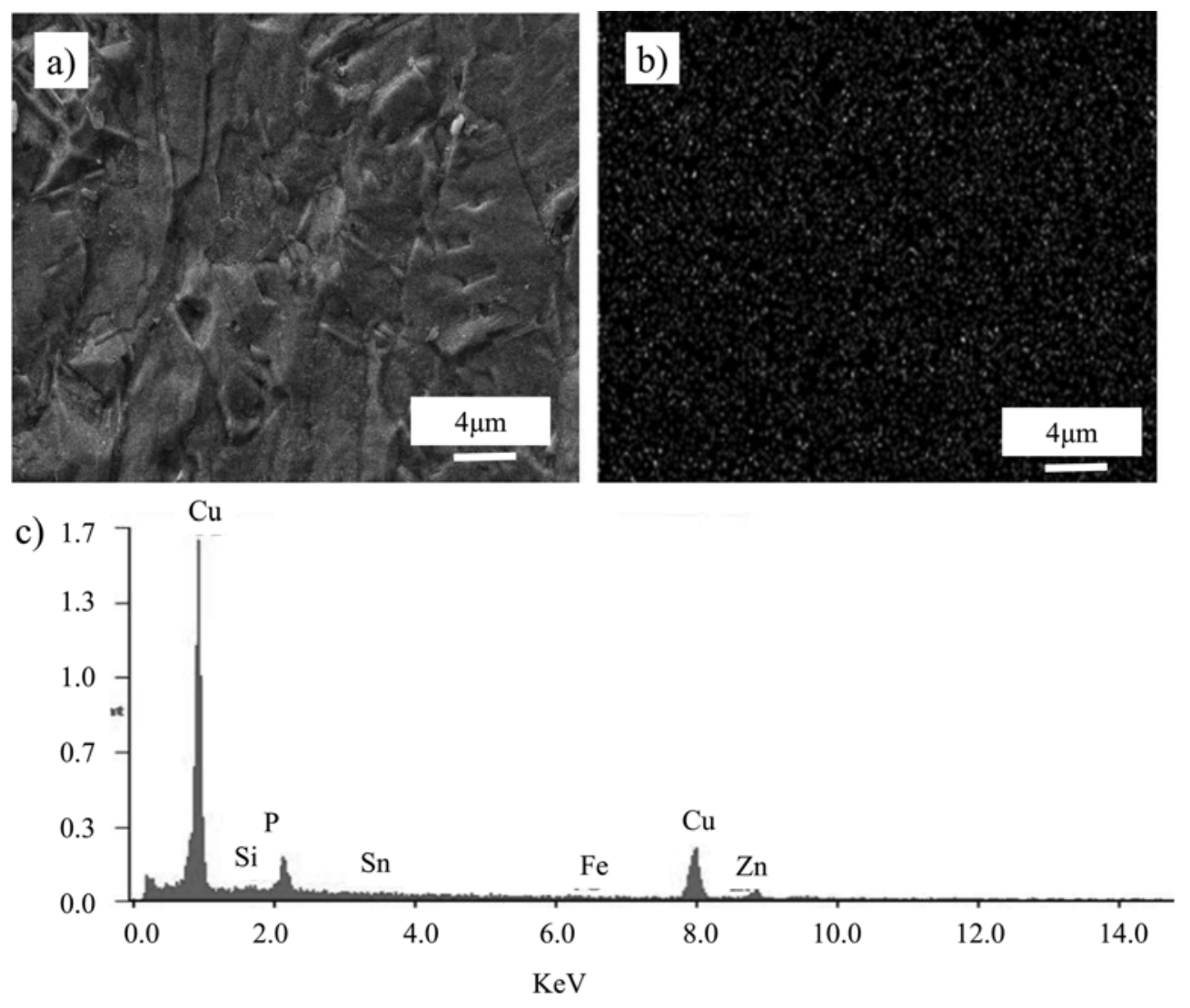

Fig. 3. SEM image (a) and EDS analysis $(b, c)$ of Sn added alloy.

\subsection{2 경도시험}

최종 완제 샘플소재의 표면 경도측정을 위해 Vickers 경도기 (Matsuzawa, model DVK-1S)를 사용하여 하중 $1 \mathrm{kgf}$, 하중 유지시간 15 초로 10 회 반복측정 후 평균치 로 측정하였다.

\section{3. 결과 및 고찰}

\section{1 주괴의 마이크로 조직 관찰}

주조한 주괴의 주조방향에 수직인 절단면의 미세 단면 조직을 관찰하였으며, 그 결과를 Fig. 2에 나타내었다. 그 림에서 보듯이 단면조직은 $\mathrm{PMC} 90$ 소재에 비하여 $\mathrm{Sn}$ 첨 가시 수지상정이 큰 차이가 보이지않으나, $\mathrm{Mg}$ 첨가시 수 지상이 현저하게 미세하게 나타났다. $\mathrm{Mg}$ 이 $0.025 \%$ 이상 첨 가될 때 주괴조직이 미세화된다는 것은 Tetsuto등ํ의 보 고와 잘 일치하고 있다. 이러한 사실로 미루어 볼 때 이 후 압연 및 열처리시 조직 미세화에 따른 강도 및 내 연화성 개선의 효과가 있을 것으로 판단된다.

본 연구에서 $480^{\circ} \mathrm{C}$ 에서 6시간 시효처리후의 조직관찰 과 동일부위에 대한 $\mathrm{Sn}$ 분포를 주사전자현미경으로 이미지 맵핑을 실시한 결과를 Fig. 3에 나타내었다. 사진에서 보 이듯, 조직내 $\mathrm{Sn}$ 은 기지에 균일하게 분산되어 있는 것으 

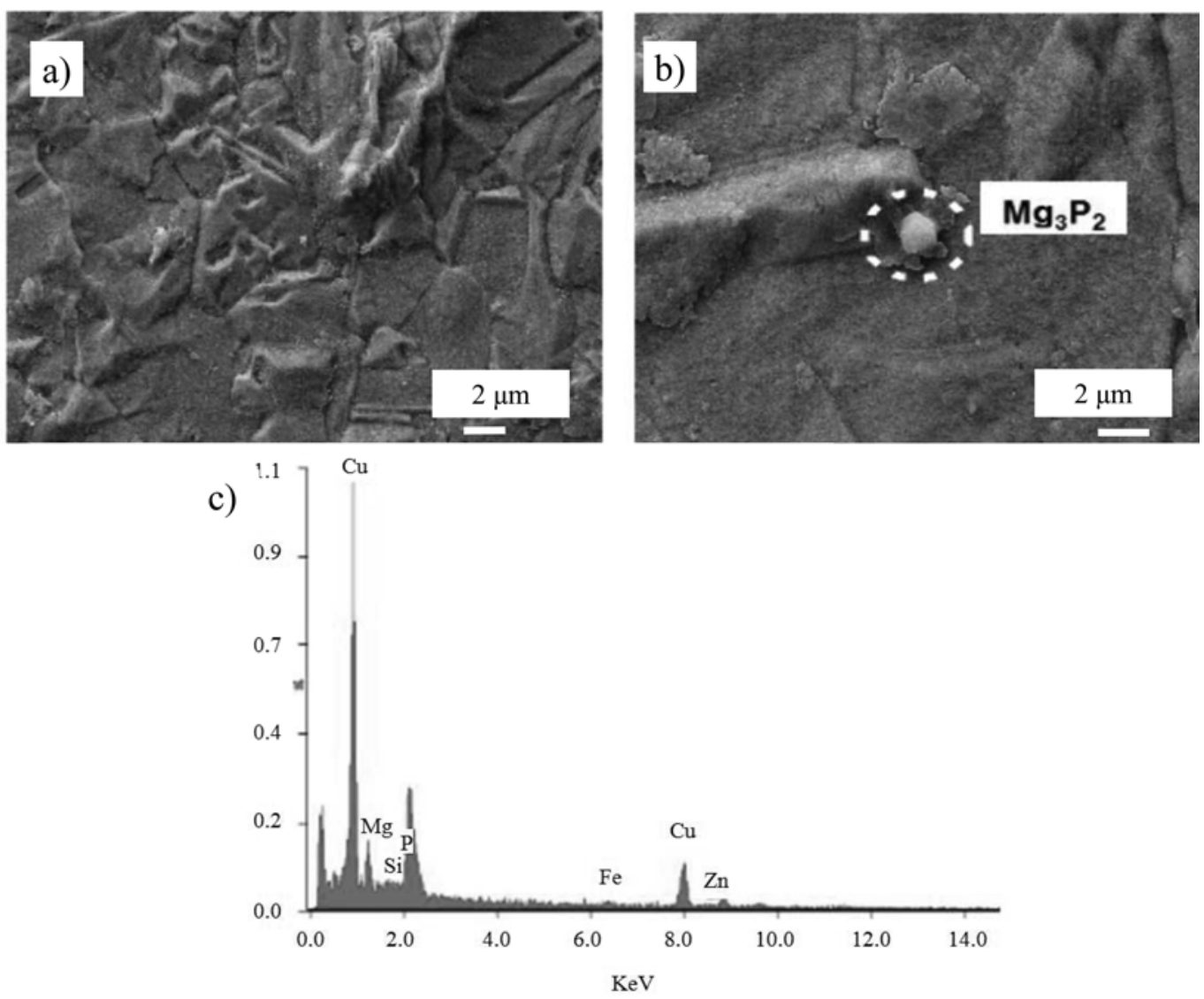

Fig. 4. SEM image (a), (b) and EDS analysis (c) of precipitationof Mg added alloy.

로 나타났으며, 이러한 결과로부터 기지내 고용강화 효 과가 있을 것으로 생각된다.

\section{2 석출물 관찰}

$\mathrm{Cu}-\mathrm{Fe}-\mathrm{P}$ 계 합금의 인장강도 및 내연화특성에 영향을 미 치는 석출물에 대한 정량적인 관찰을 위하여 $480^{\circ} \mathrm{C}$ 시효 처리후 냉간압연조직을 주사전자현미경 및 투과전자현미 경을 통하여 석출물의 크기, 분포 및 결정구조를 관찰하 였다.

고용강화기구인 $\mathrm{Sn}$ 첨가 합금을 제외한 $\mathrm{Mg}$ 첨가합금의 석출상의 형성에 대해 정량적 관찰을 실시하였다. $\mathrm{Cu}$ 기 지내 $\mathrm{Mg}$ 을 첨가한 합금에 대한 주사전자현미경 조직을 관 찰하였으며, 그 결과를 Fig. 4에 나타내었으며, 투과전자 현미경 조직은 Fig. 5 및 Fig. 6에 나타내었다.

Fig. 4에서 보듯이, Probe의 크기가 커서 주사되는 범 위가 넓어 $\mathrm{Cu}$ 기지에 타원소 성분이 일부 동시에 검출됨 으로써 석출물의 정량적인 분석이 난이하였다. 이들 석 출물에 대한 정량적인 분석을 행하기 위하여 투과전자현 미경 조직관찰을 실시하였다.

$\mathrm{TEM}$ 을 이용하여 [111] 정대축에서의 명시야상 및 회절 상을 관찰하였으며, 그 결과는 Fig. 5과 같다. Fig. 6에서 보듯이 입계에 주로 미세하게 분산된 $\mathrm{Mg}-\mathrm{P}$ 석출물이 관

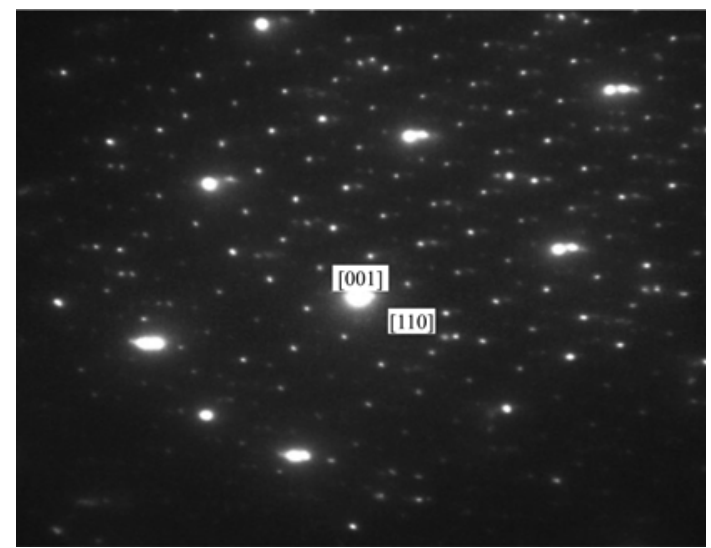

Fig. 5. TEM micrograph and electrical diffraction pattern of $\mathrm{Cu}$ matrix and precipitation of $\mathrm{Mg}$ base, SADP with [111] zone axis.

찰되었으며, TEM 분석결과 Mg-P계 화합물은 약 $100 \mathrm{~nm}$ 크기의 $\mathrm{a}=12.01 \AA$ 의 격자상수를 갖는 $\mathrm{Mg}_{3} \mathrm{P}_{2}$ 인 것으로 확인하였다. $\mathrm{Mg}$ 함량이 증가함에 따라 기지에 미세하게 분산된 $\mathrm{Mg}_{3} \mathrm{P}_{2}$ 석출물의 분포 또한 증가하였으며, 이러 한 결과로 볼 때, 석출물인 $\mathrm{Mg}_{3} \mathrm{P}_{2}$ 가 인장강도 및 내연 화특성 향상의 강화기구로 작용한 것으로 사료된다.

현재까지, $\mathrm{Mg}-\mathrm{P}$ 화합물에 대한 연구보고가 적으나, 일 

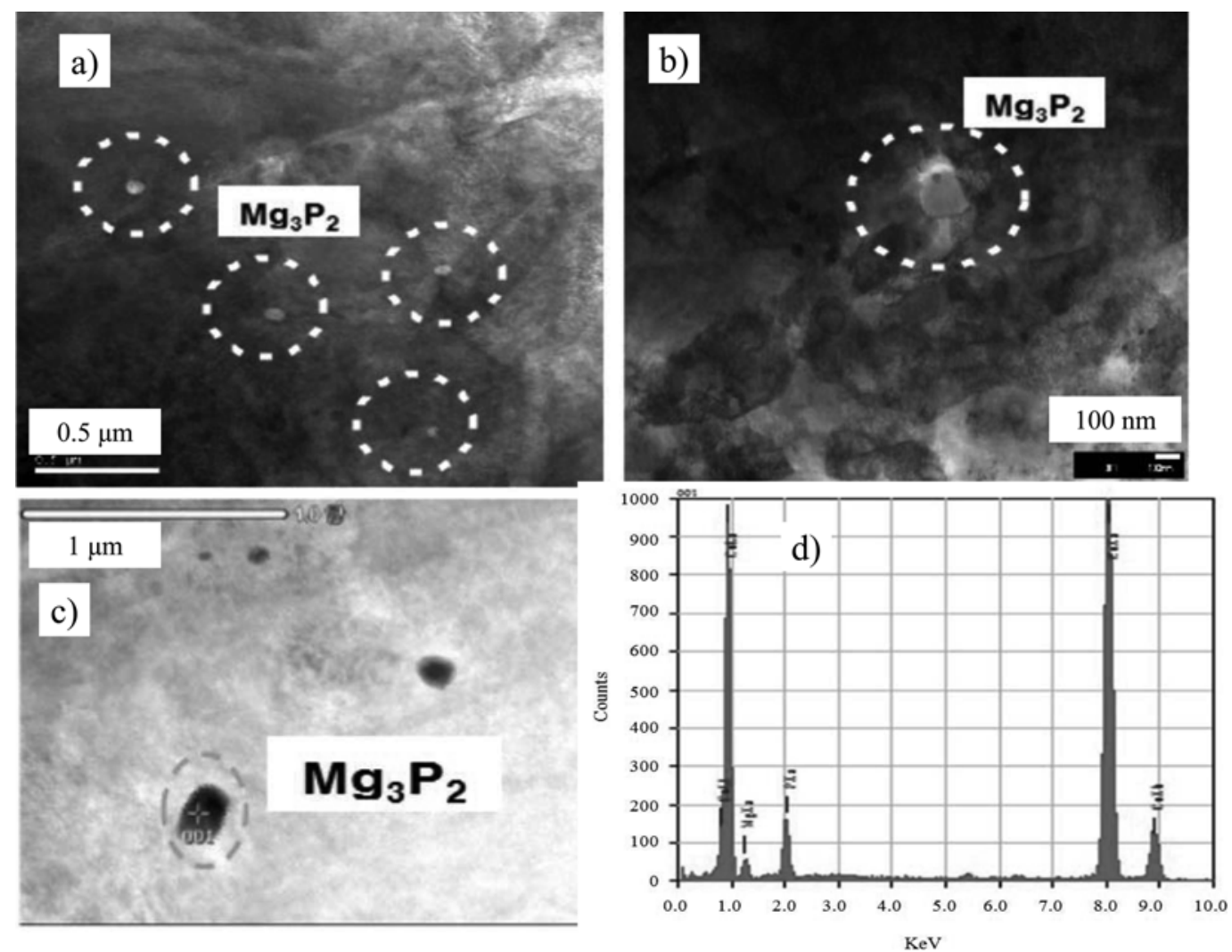

Fig. 6. (a, b, c) TEM image of $\mathrm{Mg}_{3} \mathrm{P}_{2}$ compound on the matrix, (d) EDS analysis of $\mathrm{Mg}_{3} \mathrm{P}_{2}$ compound.

Table 2. Mechanical properties and electrical conductivity of Alloys and comparative alloys.

\begin{tabular}{ccc}
\hline & $\begin{array}{c}\mathrm{TS} \\
\left(\mathrm{kgf} / \mathrm{mm}^{2}\right)\end{array}$ & $\begin{array}{c}\mathrm{EC} \\
(\% \mathrm{IACS})\end{array}$ \\
\hline 1 & 48.8 & 74.6 \\
2 & 50.6 & 70.1 \\
3 & 51.9 & 67.4 \\
4 & 51.7 & 66.7 \\
5 & 53.1 & 64.0 \\
6 & 53.4 & 63.9 \\
7 & 38.0 & 85.0 \\
\hline
\end{tabular}

부 알려진 바로는 $\mathrm{Guo}$ 등 ${ }^{5}$ 에 의하면 화학양론비(mass\%) $\mathrm{Mg} / \mathrm{P}=0.6 \sim 2.5$ 일 때 전기전도도의 저하없이 최적의 $\mathrm{Mg}_{3} \mathrm{P}_{2}$ 가 형성되며, 그 크기는 $0.2 \sim 1 \mu \mathrm{m}$ 로 인장강도 및 내연화 특성향상에 영향을 미치는 것으로 알려져 있다. 따라서 상 기의 결과로부터 모합금에 $\mathrm{Mg}$ 을 첨가한 경우 $480^{\circ} \mathrm{C}$ 에서 시효할 때 석출하는 $\mathrm{Mg}$-P화합물은 $\mathrm{Mg}_{3} \mathrm{P}_{2}$ 임을 확인할 수 있었다.

\section{3 기계적 특성 및 물리적 특성 조사}

Table 2에 각 시편에서 측정한 인장강도, 전기전도도 및 경도를 나타내었으며, 각 원소별 첨가량에 따른 물리적 특 성을 Fig. 7에 나타내었다.

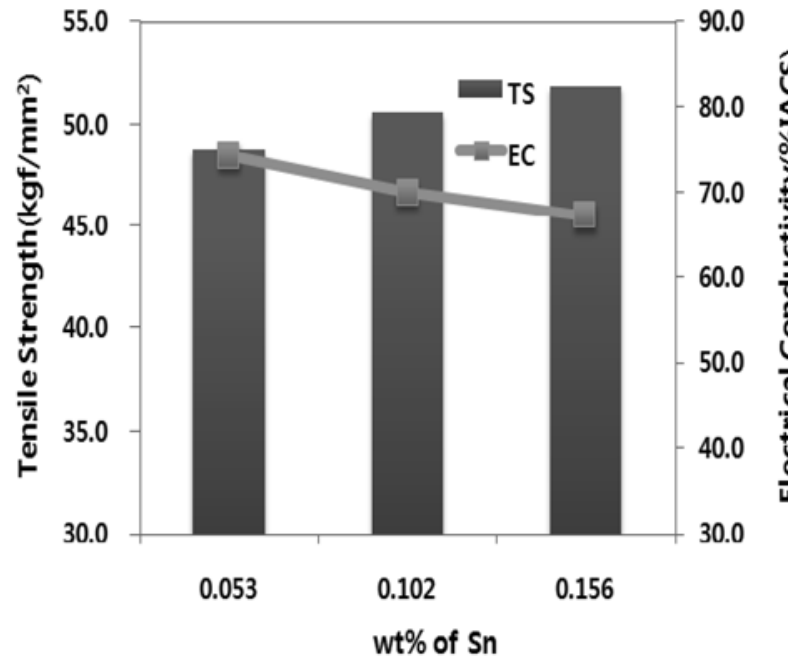

Fig. 7. The change of tensile strength (TS) andelectrical conductivuty (EC) in Sn added alloys.

Fig. 7에서는 모합금에 $\mathrm{Sn}$ 함량을 $0.053 \mathrm{wt} \%, 0.102 \mathrm{wt} \%$ 및 $0.156 \mathrm{wt} \%$ 각각 첨가된 합금에 대해 각 조성에 따른 인장강도와 전기전도도의 변화를 나타내었다. 그림에서 보 듯이 인장강도는 $\mathrm{Sn}$ 함량이 증가함에 따라 각각 $48.8 \mathrm{~kg} / \mathrm{mm}^{2}$, $50.6 \mathrm{~kg} / \mathrm{mm}^{2}, 51.9 \mathrm{~kg} / \mathrm{mm}^{2}$ 로 증가하였으며, 전기전도도는 각각 $74.6 \% \mathrm{IACS}, 70.1 \% \mathrm{IACS}, 67.4 \% \mathrm{IACS}$ 로 감소하는 


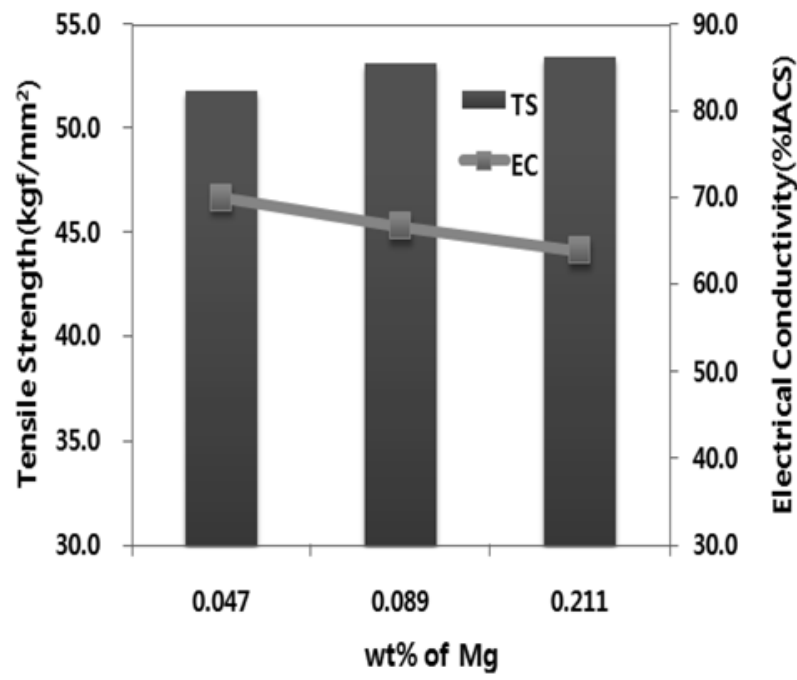

Fig. 8. The change of Tensile strength (TS) and electrical conductivity (EC) in Mg added alloys.

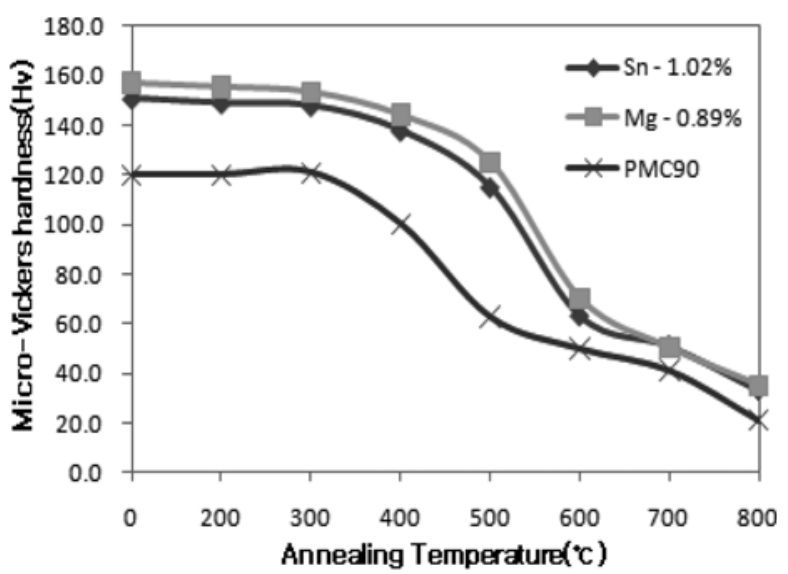

Fig. 9. Variation of Micro-Vickers hardness of alloys with varied annealing temperature for $30 \mathrm{~min}$.

것을 알 수 있었다.

Fig. 3에서 살펴본 바와같이 $\mathrm{Sn}$ 첨가시 $\mathrm{Cu}$ 기지에 일 부 $\mathrm{Fe}$ 석출을 억제하며, 동시에 $\mathrm{Cu}$ 기지내 전면에 $\mathrm{Sn}$ 성 분이 분산되어 고용됨에 따라 $\mathrm{Sn}$ 성분의 고용강화에 따 른 효과가 인장강도 향상의 강화기구로 작용한 것으로 생 각된다

또한, 모합금에 $\mathrm{Mg}$ 함량을 $0.047 \mathrm{wt} \%, 0.089 \mathrm{wt} \%$ 및 $0.211 \mathrm{wt} \%$ 각각 첨가하였을 때 각 조성에 따른 인장강도 와 전기전도도의 변화를 조사하였으며 그 결과를 Fig. 8 에 나타내었다. 그림에서 보듯이 인장강도는 $\mathrm{Mg}$ 함량이 증 가함에 따라 $51.7 \mathrm{~kg} / \mathrm{mm}^{2}, 53.1 \mathrm{~kg} / \mathrm{mm}^{2}$ 및 $53.4 \mathrm{~kg} / \mathrm{mm}^{2}$ 로 증가하였으며, 전기전도도는 $70.8 \% \mathrm{IACS}, 66.9 \% \mathrm{IACS}$ 및 $63.9 \% \mathrm{IACS}$ 로 각각 감소하는 것을 알 수 있었다.

기지에 $\mathrm{Mg}$ 첨가로 주조조직 미세화에 따른 가공조직 의 미세화 및 $\mathrm{Cu}$ 기지에 $\mathrm{Fe}-\mathrm{P}$ 석출물과 함께 $\mathrm{Mg}_{3} \mathrm{P}_{2}$ 석 출물의 생성으로 전기전도도값은 크게 떨어지지 않으나,
인장강도는 향상된 것으로 생각된다. 이는 Hiroshi'릐 $\mathrm{Mg}$ 첨가시 석출물에 따른 강도 증가에 대한 보고 내용과 잘 일치함을 알 수 있었다.

\section{4 내연화특성}

Fig. 9은 소둔 온도에 따른 합금별 내연화특성의 변화 를 나타낸 것이다. 가열후의 경도가 초기 경도의 $80 \%$ 가 되는 온도를 내연화온도로 정의한다.

비교재인 $\mathrm{PMC} 90$ 와 $\mathrm{Cu}-\mathrm{Fe}-\mathrm{P}$ 계에 $\mathrm{Sn}$ 및 $\mathrm{Mg}$ 을 첨가한 합금을 $200^{\circ} \mathrm{C}$ 부터 $800^{\circ} \mathrm{C}$ 까지 30 분씩 가열하여 경도를 비교하였을 때, $\mathrm{PMC} 90$ 소재는 내연화 온도가 $400^{\circ} \mathrm{C}$ 로 나타났고, 특히, $\mathrm{Sn}$ 및 $\mathrm{Mg}$ 첨가시 $500 \sim 550^{\circ} \mathrm{C}$ 로 내연화 온도가 향상되는 것으로 나타났다.

$\mathrm{Sn}$ 및 $\mathrm{Mg}$ 을 첨가한 합금들은 내연화특성 향상에 모두 우수한 것을 알 수 있었으며, $\mathrm{Sn}$ 은 기지내 미세하게 분 산 고용됨에 따라 Fe-P 석출물의 재고용을 억제하는 역 할을 하는 것으로 생각되며, $\mathrm{Mg}$ 의 경우 $\mathrm{Cu}$ 기지내 주 로 입계에 미세하게 분산하여 $\mathrm{Mg} 3 \mathrm{P} 2$ 석출물이 시효가 진 행됨에 따라 입계 이동을 억제하는 역할을 하여 내연화 특성이 증가한 것으로 사료된다.

\section{4. 결 론}

$\mathrm{Cu}-\mathrm{Fe}-\mathrm{P}$ 계 합금의 강도와 전기전도도에 미치는 $\mathrm{Sn}$ 및 $\mathrm{Mg}$ 미량 첨가원소의 영향을 조사한 결과 다음과 같은 결 론을 얻을 수 있었다.

1. 모합금에 $\mathrm{Sn}$ 및 $\mathrm{Mg}$ 성분을 미량첨가시 비교재인 $\mathrm{PMC} 90$ 에 비하여 인장강도는 모두 증가하였다.

2. 전기전도도는 $\mathrm{Sn}$ 및 $\mathrm{Mg}$ 을 첨가시 $\mathrm{PMC} 90$ 에 비해 상대적으로 감소하였다.

3. 내연화특성은 $\mathrm{Sn}$ 및 $\mathrm{Mg}$ 첨가시 $\mathrm{PMC} 90$ 에 비해 모 두 증가하는 것을 확인할 수 있었다.

4. 모합금에 $\mathrm{Mg}$ 첨가시 조직내 미세 석출물을 $\mathrm{TEM}$ 을 통해 관찰할 수 있었으며, 석출물은 [111] 정대축에 약 $100 \mathrm{~nm}$ 크기의 $\mathrm{a}=12.01 \AA$ 의 격자상수를 가진 $\mathrm{Mg}_{3} \mathrm{P}_{2}$ 였으 며, 주로 입계에 분산되어 석출됨을 확인할 수 있었다.

\section{참 고 문 헌}

1. M. Tetsuto, J. Copper and Brass(in Japanese), 41, 204 (2002).

2. A. Hiroshi, J. Japan Copper and Brass Assoc.(in Japanese), 37, 302 (1998).

3. C. -S. Han and K. -W. Koo, Kor. J. Mater. Res., 18(1), 51 (2008).

4. S. -H. Lee, Kor. J. Mater. Res., 18(9), 492 (2008).

5. F. A. Guo, C. J. Xiang, C. X. Yang, X. M. Cao, S. G. Mu, Y. Q. Tang, Mat. Sci. Eng. B, 147(1), 1 (2008).

6. R. N. Caron and J. F. Brredies, US Patent, 4,594,221 (1986). 
7. Y. Konishi, T. Kashibuchi and F. Sakakibara, J.Japan Inst. Metals, 7, 95 (1943).

8. H. Fujiwara, T. Sato and A. Kamio, J. Japan Inst. Metals, 59, 502 (1995).

9. A. V. Kumanin, Russian Metallurgy and Mining, 6, 182
(1987).

10. J. Miyake and M. E. Fine, Scripta Metall., 25, 1573 (1991).

11. K. Kita, J. Mater. Sci. Jpn., 49(5), 482 (2000).

12. H. J. Fisher, D. A Hay and W. L. Finlay, J. Inst. Met., 98, 368 (1970). 